\title{
STUDENTS' LEARNING STYLE IN STUDYING VOCABULARY AT EIGHTH GRADE STUDENTS OF SMP SWASTA BUDISATRYA MEDAN
}

\author{
AN ARTICLE \\ Submitted in Partial Fulfillment of the Requiretment \\ for the Degree of Sarjana Pendidikan
}

By :

DINA AZIZAH LUBIS

Registration Number: 2123321021

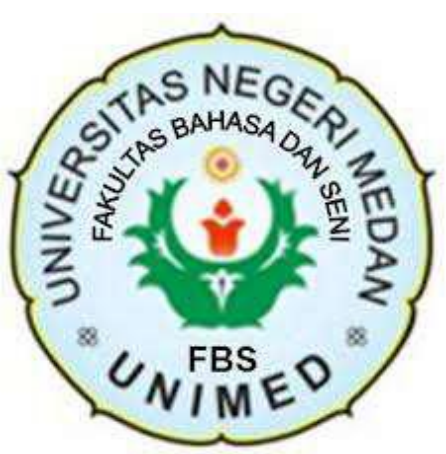

ENGLISH AND LITERATURE DEPARTMENT

FACULTY OF LANGUAGES AND ARTS STATE UNIVERSITY OF MEDAN 


\title{
ARTIKEL \\ STUDENTS' LEARNING STYLE IN STUDYING VOCABULARY AT EIGHTH GRADE STUDENTS OF SMP SWASTA BUDISATRYA MEDAN
}

\author{
Disusun dan Diajukan oleh: \\ DINA AZIZAH LUBIS \\ NIM. 2123321021
}

Telah diverifikasi dan dinyatakan memenuhi syarat untuk diunggah pada jurnal online

Medan, Juli 2017

Menyetujui

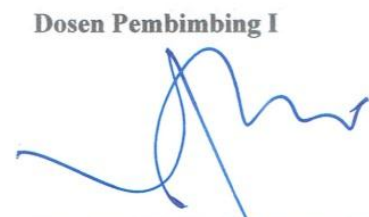

Dr. Anni Holila Pukungan, M.Hum NIP. 197005222001122002
Dosen Pembimabing II

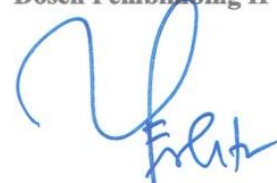

Yeni Erlita, S.Pd., M.Hum NIP. 19790321 2008122002

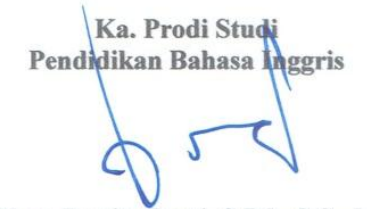

Nora Ronita Dewi, S.Pd., S.S., M.Hum.

NIP. 198005222008122003 


\title{
STUDENTS' LEARNING STYLE IN STUDYING VOCABULARY AT EIGHTH GRADE STUDENTS OF \\ SMP SWASTA BUDISATRYA MEDAN
}

\author{
*Dina Azizah Lubis \\ **Anni Holila Pulungan \\ **Yeni Erlita
}

\begin{abstract}
Azizah, Dina Lubis. 2123321021. Students Learning Style in Studying Vocabulary at Eighth Grade Students of SMP Swasta Budisatrya Medan. A Thesis. English and Literature Department. Faculty of Languages and Arts. State University of Medan. 2017.

The study discusses about Students Learning Style in Studying Vocabulary at Eighth Grade Students of SMP Swasta Budisatrya Medan. The objective of the study is to investigate type of students learning style in studying vocabulary and to analyze how is the VARK learning style applied in studying vocabulary at eighth grade students of SMP Swasta Budisatrya Medan in academic year 2016/2017. There were 38 students in the class of VIII-1 as the subject of this research. This study was conducted by using qualitative research. In this study, the researcher collected the data by using questionnaire and observation task sheet. The questionnaire designed by Fleming (2001). The result showed that the type of students learning style was Visual (15.7\%), Aural (18.4\%), Read/ Write (55.2\%), and Kinesthetic $(10.5 \%)$. It means that there was 6 of 38 students was visual preference, 7 of 38 students was aural preference, 21 of 38 students was read/ write and 4 of 38 students was kinesthetic. The result of the data showed that VARK model was very helpful in teaching learning process especially in studying vocabulary.
\end{abstract}

Keywords: Learning Style, VARK, Vocabulary.

*Graduate Status

***ecturer Status 


\section{INTRODUCTION}

Background of the study

Learning is a process of interaction to the all situation around the individual environment. It can be also called as process of guidance to the objectives and doing through experiences, those are seeing, observing, and comprehending about something (Rusman, 2011). Learning is a process to acquire knowledge, skill, behavior, attitude, or values through experience, study, or education which cause a change that can be measured by brain as been called memory(Jensen \& Nickelsen, 2011: 8).

In learning someone has tendency to have one favour style, it calls learning style (DePorter\&Henarcki, 1992). Fleming (2001) defines learning style as an individual'scharacteristics and preferred ways of gathering, organizing, and thinking about information. There are VARK model to investigate students learning style. VARK is in the category of instructionalpreference because it deals with perceptual modes. VARK stands for Visual (V), Aural (A), Read/Write (R) and Kinesthetic (K).

Learning styles also needs in studying vocabulary. Because, the learning style can make the students know their way to learn. In learning language, one of components to master English is vocabulary. Because, vocabulary is basic skill of students in learn English language. It usually serves as useful and fundamental tool for communicating and acquiring knowledge.

Vocabulary is important but students still have any difficulties in mastering vocabulary in SMP Swasta Budisatrya Medan. It observed by interview 
the English teachers and 10 students in the eighth grade students of SMP. The students said that they do not understand about Visual, Aural, Read/ Write, and Kinesthetic (VARK) learning style truly. Based on English teacher experience in teaching English in the school said that the students do not know what is the type of their learning style. Then, the teachers also do not apply learning style when teaching English.

There are so many things should be prepared such as, the material that appropriate with students' learning styles, the way how she/he applies the material and how to be a good entertainer to their students to provide the material. Whereas if the teachers identify the learning styles of their students exactly the teachers will find the right method to provide the materials for students to learn vocabulary.

It was found that the teacher just asked the students to memorize the list word and finding the meaning. The teachers don't know the how to make the students easier in studying vocabulary. The reality is the teachers feel so hard to teach their students based on the learning style.

Based on factors that are mentioned above the researcher found the biggest problem. They are to know the type of students' learning style and how the learning style applied in studying vocabulary. It is necessary to investigate the learning styles at the eighthgrade students in SMP Swasta Budisatrya Medan based on Visual, Aural, and Read/ Write and Kinesthetic (VARK) learning styles, especially in studying vocabulary. 
So, from the explanation about learning style the reseacher decided to use Fleming's VARK model. The VARK model is appropiate for analyzing the students' learning style in studying vocabulary.

\section{REVIEW OF LITERATURE}

Learning style is the way and technique that they use to learn and process information and knowledge. It helps students learn more fast and easier with selecting and using the appropriate learning style that they like. Learning styles refer to the variations in your ability to accumulate as well as assimilate information. Basically, learning style is the method that best allows you to gather and use knowledge in a specific manner.

Fleming (2001) defines learning style as an individual's characteristics and preferred ways of gathering, organizing, and thinking about information. VARK is in the category of instructional preference because it deals with perceptual modes. VARK Model allows the learner to clearly define his or her dominant learning style. VARK stands for Visual (V), Aural (A), Read/Write (R) and Kinesthetic (K).

Student's learning style is based on VARK model by Fleming. Visual learners learn best from visual images that do not include writing. Graphs and diagrams are easy for them to understand. They remember faces and places and tend to recall information by picturing it in their minds. Aural learners do well with hearing information. They remember words to songs and can recall conversations in detail by hearing them in their minds. Read/Write learners are at 
home with written material. They comprehend and remember what they read, and they often enjoy writing. Kinesthetic learners learn by doing, hands-on activities and real-life experiences help them remember.

Vocabulary is the list of words, usually arranged alphabetically and defined, explained or translated or the range of language, the stock of word at a person's command or used in particular work, branch or subject, language, etc. Scrivener (1994:73) states that vocabulary is carrier of meaning. A vocabulary usually develops with age, and serves as a useful and fundamental tool for communication and acquiring knowledge. Acquiring an extensive vocabulary is one of the largest challenges in learning second language. Learner often manages to communicate in English by using the accumulative effect of individual words. Moreover, Lado (1994: 73) describes that vocabulary is a form or expression which is associated with content and meaning.

Vocabulary is key issues in language learning process because every new word carries new meaning to understand other language. From the statements about vocabulary above indicate that vocabulary is very important in learning language and it has important role in learning language.

\section{RESEARCH METHODOLOGY}

Methodology

In conducting this research, this research used descriptive qualitative research. Patton and cochran (2012) stated that qualitative research is characterized by its aims and its methods which generate words, rather than 
numbers, as data for analysis. Descriptive study was those studies which are concerned with describing the characteristics of a particular individual, or of a group, whereas, diagnostic research studies determine the frequency with which something occurs or its association with something else (Kothari, 1990:37).

One of the types of qualitative research that will be use in this research was questionnaire. Questionnaire was a technique of data collection by giving aset of questions or a written statement to the respondent to answer (Kothari, 1990:48). The questionnaire was to get the type learning styles at the eighth grade students of SMP Swasta Budisatrya Medan. There were16 questions of Visual learning style, Aural learning style, Read/ Write learning style and Kinesthetic learning style (VARK).

\section{Data Collection}

Data collection was important to determine the result of the study. The data collected through questionnaires and observation in the classroom. Finally, the questionnaires distributed to the students and then the students fill out the questionnaires based on the instructions contain in the questionnaires. After the students finish fill the questionnaires, the questionnaires would be collect and analyze. For the next, make observation in the classroom, more precisely observed which students' learning styles in studying vocabulary. 


\section{Instruments}

\section{Questionnaire}

Questionnaire was a technique of data collection by giving a set of questions or a written statement to the respondent to answer. The questionnaires which answered by the students consists of 16 questions by Fleming (2001) in version 7.0 Questionnaire was in multiple choice. The 16 questions in the questionnaire were designed by Fleming (2001). The 16 questions are about perception or opinion of social phenomenon. The students would ask to circle one the answer that they feel appropriate with them. The VARK questionnaire indicated learners preference for the way their work with information. The questionnaire can helped the researcher to know each student's learning style in the vocabulary learning process.

\section{Observation}

Observation was recording sistematically to phenomenon investigated (Aminatun, 2013). An observation method used observation guidelines in the form of check list as a research instrument. Format compiled lists of activities to be observed. (Aminatun, 2013) reveals that the social situation composed of three components, namely the place, actor, activities.

\section{Data Analysis}

The dataanalyzed right after they are collecting. The analysis of data based on the questionnaires. The questionnaire that distributed earlier to students then collected and checked the answer. Then, questionnaire would be calculate to find 
learning style of a class at the eighth grade students of SMP Swasta Budisatrya Medan. In the questionnaire, there were 16 questions with 4 multiple choices. It is A, B, C, and D. the multiple choices consist of for Visual learners, Aural learners, Read/ Write learners, and Kinesthetic learners. For scoring the questionnaire, the dominant answer or the highest score of the multiple choices showed the type students learning style.

After the VARK questionnairewere analyzed, it found what the type of learning style at the eighth grade students of SMP. Then, do the observation to find whose students that showed how the learning style applied in learning process of memorizing vocabulary.

\section{FINDINGS}

The data findings are displayed in the form of description. The researcher analyzed the learning process of students learning style applied in studying vocabulary. In the following, the researcher presents the result of observation by which implemented Fleming VARK model. The result will be explained by the researcher per type and percentage of the data.

The first research in this study the researcher was distributed student's learning style questionnaire. It was done on February 21, 2017. In this section, the researcher distributed learning style questionnaire to the 38 students as sample of this research. It contains 16 questions (see appendix 1). Students choose an answer by circle the options that they prefer. After checked the questionnaire, the 
researcher found that there were four types of the students learning style in studying vocabulary.

The researcher found that a visual learner used vision as the main sensory receiver. They tend to think in pictures. The researcher gave the word picture for the task (see appendix 2). When the students did the task, they saw the picture and read the word of vocabulary that consists of 12 words. Then, they imagine and remember the word of the picture. Because, Visual learners easier in remembering the vocabulary picture and guessing the meaning through the picture.

Aural learners perceive the world through sounds. They learn best by hearing information. The researcher gave the list of word in vocabulary task (see appendix 2). When remembering the vocabulary, they discussed the word about the meaning and pronunciation of the word. Then, they asked their friends to hearing what their friend said. So, they were easier remembering vocabulary through hearing and discussing it.

Read/ Write learners involve a variety of ways to present new vocabulary to students. This style involves reading and writing in all its forms and preferred to use wordlists and dictionaries (see appendix 2). So, in this observation the researcher gave the vocabulary task with rearranged the word and matching it to the meaning. When they did the task, they read the words in the dictionary and wrote it in the task. Automatically, they remembered the vocabulary without hard to memorize. Because, they were easier in remembering the word when they read and find the meaning in the dictionary. 
Kinesthetic learners learn best through physical activities. Their muscles play a huge role in learning. The researcher gave the word search game and matching the word to the right picture (see appendix 2). When the students did the task, they like to touch or hold thing around them. Because, they were easier in remember the words when they touch something or other things near them. Then, some of them like to shake their part of body such as hand, foot, and finger.

From the observation, the researcher found the students learning style and get the data of 38 students. In VARK learning style of studying vocabulary, the researcher found that the type Visual learners were 6 students (15,7\%), Aural learners were 7 students $(18,4 \%)$, Read/ Write Learners $(55,2 \%)$ and Kinesthetic learners were 4 students $(10,5 \%)$. As a result, there was the type of studentslearning style at eight grade students of SMP Swasta Budisatrya Medan. The researcher also made the chart of students' learning style as below:

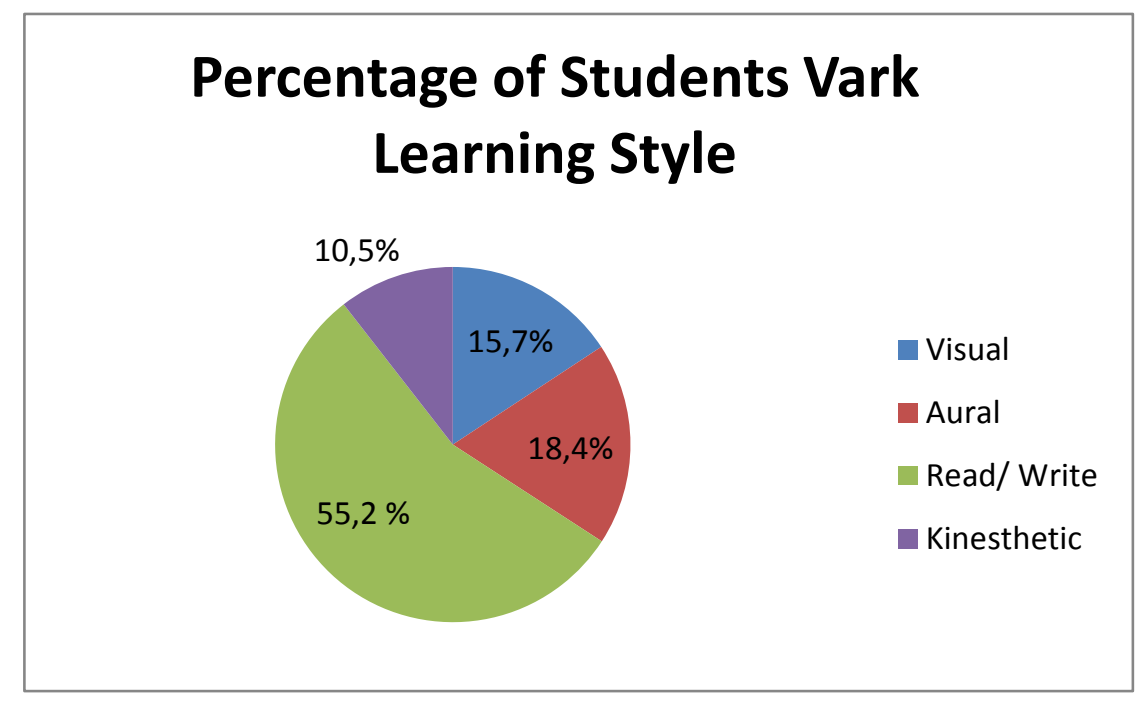

Figure 4.1 Chart of Students' Learning Style in Studying Vocabulary. 


\title{
CONCLUSIONS AND SUGGESTIONS
}

\author{
Conclusions
}

After analyzing the data was of the types of students learning style in studying vocabulary at Eighth Grade Students of SMP Swasta Budisatrya Medan. It has been found that there have $15.7 \%$ Visual, 18.4\% Aural, 55.2\% Read/ Write and $10.5 \%$ Kinesthetic. The main data gathered through questionnaire and observation. The percentage showed that 6 of 38 students were Visual learners, 7 of 38 students were Aural learners, 21 of 38 students were Read/ Write learners and 4 of 38 students were Kinesthetic learners.

VARK learning style applied in studying vocabulary by using the appropriate task and way based on the students learning style was success to solve the students' problem in memorizing vocabulary. The result was the students easier to memorize the word by using Picture word task was for Visual learners. Wordlist and discussion was for Aural learners. The rearrange word, matching the words, and finding the meaning in dictionary was for Read/ Write learners, word search game and matching the word to the picture was for Kinesthetic learners.

So, the result of applying VARK learning styles make the students easier in studying vocabulary especially in remembering the words. It is important to use VARK learning style in effectiveness and additional teaching learning process. Due to the research finding of this study, it is obtained that VARK model by Fleming is very useful in teaching learningprocess and give good affect for help the students learn faster and easier in remembering the vocabulary as the basic skill of learning English. 


\section{The Suggestions}

Based on the data findings and what this research intended to, it suggested thatfor the students, the students expected to know their learning style to easier them in doing their assignment. They also expected to focus their attention during the learning process so that they can get the point of learning, especially in studying vocabulary. Furthermore, the students applied their learning style in learning process to practicing and to make them more know about their way in learning.

For the teachers, the teacher expected to know the students learning style. They can prepare appropriate material, task, and strategies based on the students learning style in teaching process. 


\section{REFERENCES}

Aminatum, A. 2013.Gaya Belajar Peserta Didik Berprestasi Akademik Kelas IV SD Negeri Sumber Rejo Metroyu dan Magelang Jawa Tengan Tahun Akademik 2012/2013. Thesis.Faculty of Science Education, Negeri Yogyakarta University. Jakarta: Depdikbud.

DePorter, B. 1999.Quantum Learning: Membiasakan Belajar Nyaman dan Menyenangkan. Bandung: KAIFA.

Dunn, Rita, Griggs, S. A. 2002. Multiculturalism and Learning Style.Westport : Greenwood Publishing Group.

Fleming, N.D. 2001. Teaching and Learning Styles: VARK Strategies. Published by the author, Christchurch, New Zealand, 5th edition, 2001.

Jensen, Eric \& LeAnn Nickelsen. 2011. Deeper Learning: 7 Strategi Luar Biasa untuk Pembelajaran yang Mendalam dan Tak Terlupakan. Jakarta: PT.indeks.

Kothari, C.R. 1990. Research Methodology: Methods and Techniques. India: New Age International.

Nana, S. 1990. Penilaian Hasil Belajar Proses Belajar Mengajar. Bandung: PT. Remaja Rosdakarya.

Pritchard, A. 2009.Ways of Learning. New York :Routledge

Scrivener, J. 1994.Learning Teaching: A Guide for English Language Teacher. Oxford: Heinemann.

Taylor, L. 1990. Teaching and Learning Vocabulary. Herefordshire, UK: Prentice Hall international. 